\title{
Identification and Characterization of Component Organic and Glycosidic Acids of Crude Resin Glycoside Fraction from Calystegia soldanella
}

\author{
Ayako Takigawa, ${ }^{a}$ Hiroaki Setoguchi,${ }^{b}$ Masafumi Okawa, ${ }^{c}$ Junei Kinjo, ${ }^{c}$ Hiroyuki Miyashita, ${ }^{d}$ \\ Kazumi Yoкомizo, ${ }^{d}$ Hitoshi Yoshimitsu, ${ }^{d}$ Toshihiro Nohara, ${ }^{d}$ and Masateru OnO ${ }^{*, a}$ \\ ${ }^{a}$ School of Agriculture, Tokai University; 5435 Minamiaso, Aso, Kumamoto 869-1404, Japan: ${ }^{b}$ Graduate School of \\ Human and Environmental Studies, Kyoto University; Yoshida Nihonmatsu-cho, Sakyo-ku, Kyoto 606-8501, Japan: \\ ${ }^{c}$ Faculty of Pharmaceutical Sciences, Fukuoka University; 8-19-1 Nanakuma, Jonan-ku, Fukuoka 814-0180, Japan: and \\ ${ }^{d}$ Faculty of Pharmaceutical Sciences, Sojo University; 4-22-2 Ikeda, Kumamoto 860-0082, Japan. \\ Received April 5, 2011; accepted June 17, 2011; published online June 22, 2011
}

\begin{abstract}
Alkaline hydrolysis of the crude resin glycoside fraction of the leaves, stems, and roots of Calystegia soldanella Roem. et Schult. (Convolvulaceae) gave four new glycosidic acids, named calysolic acids A, B, C, and D, along with one known glycosidic acid, soldanellic acid $\mathrm{B}$, and three organic acids, $2 S$-methylbutyric, tiglic, and $2 S, 3 S$-nilic acids. The structures of the new glycosidic acids were characterized on the basis of spectroscopic data and chemical evidence.
\end{abstract}

Key words resin glycoside; glycosidic acid; Calystegia soldanella; Convolvulaceae; organic acid; calysolic acid

Calystegia soldanella Roem. et Schult. (Convolvulaceae) is widely distributed on temperate sandy beaches of seas and lakes. The root of this plant is used for the treatment of arthritis. ${ }^{1)}$ The isolation and structural elucidation were reported for two genuine resin glycosides, soldanellines A and $\mathrm{B}$, as chemical constituents of the root. ${ }^{2,3)}$ Prior to reinvestigation of the genuine resin glycosides of this plant, we examined the chemical components of the crude resin glycoside fraction of the leaves, stems, and roots of $C$. soldanella. This paper deals with the isolation and structural elucidation of four new glycosidic acids along with one known glycosidic acid and three known organic acids.

The flesh leaves, stems, and roots of $C$. soldanella were extracted with methanol $(\mathrm{MeOH})$. This extract was partitioned between ethyl acetate (EtOAc) and $\mathrm{H}_{2} \mathrm{O}$. The EtOAcsoluble fraction was subjected to Sephadex LH-20 column chromatography to afford a crude resin glycoside fraction. The alkaline hydrolysis product of part of the fraction was fractionated into organic acid and glycosidic acid fractions.

The organic acid fraction was acylated with $p$-bromophenacyl bromide followed by chromatographic separation to give $p$-bromophenacyl 2-methylbutyrate (1), p-bromophenacyl tiglate (2), and $p$-bromophenacyl nilate (3) (Fig. 1). ${ }^{4)}$ The absolute configurations of $\mathbf{1}$ and $\mathbf{3}$ were defined as $S$ and $2 S, 3 S$, respectively, by comparison of the specific rotations and ${ }^{1} \mathrm{H}$-NMR spectral data for $(+)-\alpha$-methoxy- $\alpha$-trifluoromethylphenylacetic acid (MTPA) ester (3a) of $\mathbf{3}$ with those of authentic samples (Fig. 1). ${ }^{4)}$

Acidic hydrolysis of the glycosidic acid fraction gave aglycone and monosaccharide fractions. Methylation of the former with trimethylsilyldiazomethane-hexane yielded methyl $11 S$-jalapinolate (4), which was identified by ${ }^{13} \mathrm{C}$-NMR spectral data of 4 and ${ }^{1} \mathrm{H}-\mathrm{NMR}$ spectral data of $(+)$-MTPA ester (4a) of 4 (Fig. 1) ${ }^{5,6)}$ HPLC analysis with optical rotation chiral detection of the monosaccharide fraction indicated the presence of D-glucose, D-quinovose, and L-rhamnose.

The glycosidic acid fraction was treated with trimethylsilyldiazomethane-hexane and then chromatographed over HPLC on the octadecyl silica (ODS) and silica gel column to yield five methyl esters (5-9) of glycosidic acids. Upon al- kaline hydrolysis, 5-9 gave the free glycosidic acids $\mathbf{5} \mathbf{a}-$ $\mathbf{9 a}$, respectively. Compound 5a was identified as soldanellic acid B based on the physical and spectral data (Fig. 1). ${ }^{3)}$

Compound 6a, named calysolic acid A, was obtained as an amorphous powder and showed an $[\mathrm{M}-\mathrm{H}]^{-}$ion peak at $\mathrm{m} / \mathrm{z}$ 1049 along with fragment ion peaks at $\mathrm{m} / z$ 887 [1049-162 (hexosyl unit) ${ }^{-}, 725$ [887-162 $^{-}, 579$ [725-146 (6-deoxyhexosyl unit) $]^{-}, 417[579-162]^{-}$, and $271\left[^{[417-146]^{-}}\right.$in the negative-ion FAB-MS (Fig. 2). The molecular formula of 6a was analyzed as $\mathrm{C}_{46} \mathrm{H}_{82} \mathrm{O}_{26}$ by high-resolution (HR)-negative-ion FAB-MS. The ${ }^{1} \mathrm{H}-\mathrm{NMR}$ spectrum of $\mathbf{6}$, which was similar to that of $\mathbf{5}$ except for the appearance of signals due to one more glucosyl unit, showed signals due to five<smiles>CC[C@H](C)C(=O)OCc1ccccc1</smiles>

1<smiles>O=C(CCCC(=O)c1ccc(Br)cc1)c1ccccc1</smiles>

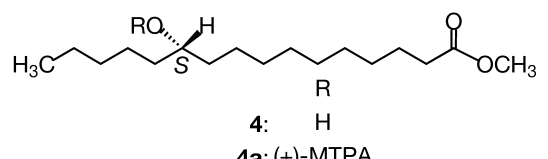
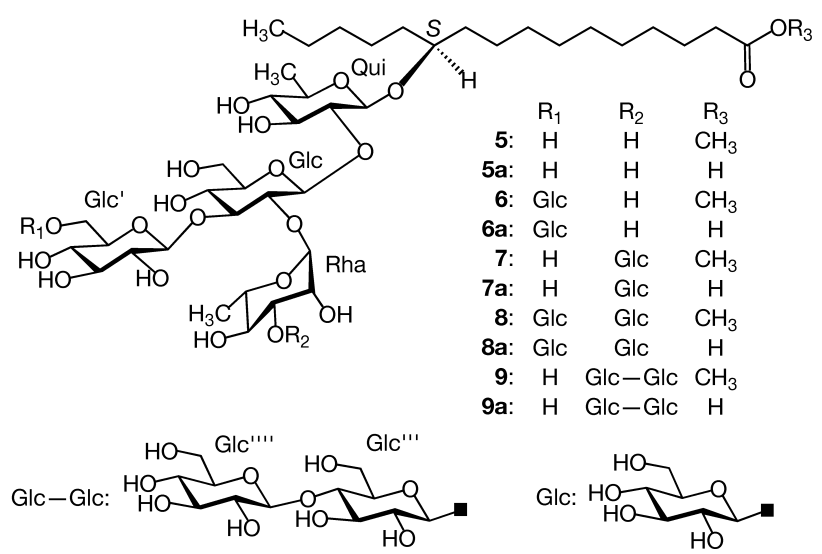

Fig. 1. Structures of $\mathbf{1}-\mathbf{9}$ and $\mathbf{3 a}-\mathbf{9 a}$ 


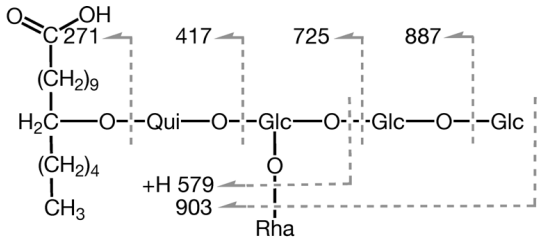

$6 a$

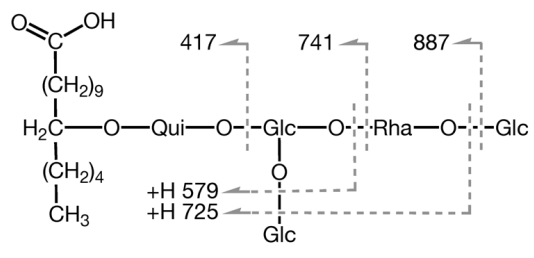

$7 a$

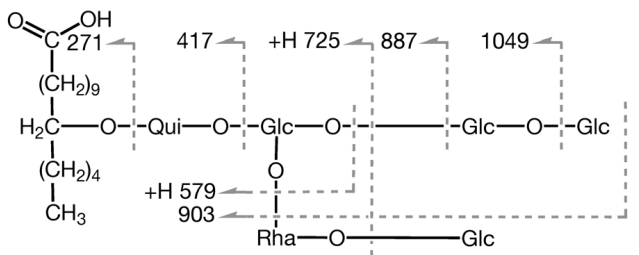

$8 a$

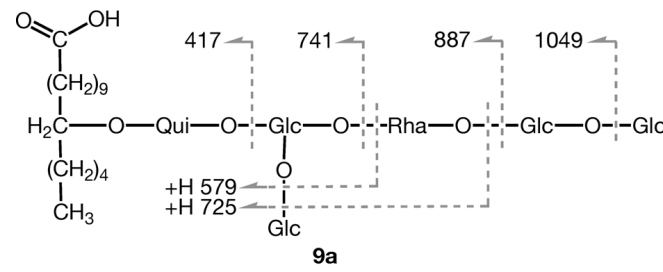

Qui, quinovopyranosyl; Glc, glucopyranosyl; Rha, rhamopyranosyl.

Fig. 2. Fragment Ions Observed in the Negative-Ion FAB-MS of $\mathbf{6 a - 9}$

anomeric protons $[\delta 6.29(1 \mathrm{H}, \mathrm{s}), 5.79(1 \mathrm{H}, \mathrm{d}, J=8.0 \mathrm{~Hz})$, $4.88(1 \mathrm{H}, \mathrm{d} . J=8.0 \mathrm{~Hz}), 4.86(1 \mathrm{H}, \mathrm{d}, J=8.0 \mathrm{~Hz}), 4.79(1 \mathrm{H}, \mathrm{d}$, $J=8.0 \mathrm{~Hz})]$ and two secondary methyl groups $[\delta 1.79(3 \mathrm{H}, \mathrm{d}$, $J=6.5 \mathrm{~Hz}), 1.57(3 \mathrm{H}, \mathrm{d}, J=6.5 \mathrm{~Hz})]$ assignable to $\mathrm{H}_{3}-6$ of $6-$ deoxyhexosyl units; this spectrum also showed signals due to one methoxy group $[\delta 3.62(3 \mathrm{H}, \mathrm{s})]$, one equivalent methylene group $[\delta 2.32(2 \mathrm{H}, \mathrm{t}, J=7.5 \mathrm{~Hz})]$ adjacent to a carbonyl group, and one primary methyl group $[\delta 0.87(3 \mathrm{H}, \mathrm{t}$, $J=7.0 \mathrm{~Hz}$ )] ascribable to the aglycone moiety (Agl). The ${ }^{13} \mathrm{C}$ NMR spectrum of $\mathbf{6}$ exhibited signals due to five anomeric carbons $(\delta 105.1,104.4,102.4,102.1,101.5)$ and one carbonyl carbon $(\delta 174.0)$. The NMR signals due to the sugar moiety were assigned with the aid of ${ }^{1} \mathrm{H}-{ }^{1} \mathrm{H}$ correlation spectroscopy (COSY), total correlation spectroscopy (TOCSY), and heteronuclear multiple quantum coherence (HMQC) spectra (Tables 1 and 2); these data suggested that 6 was composed of $1 \mathrm{~mol}$ each of methyl $11 S$-jalapinolate, Dquinovose, and L-rhamnose and $3 \mathrm{~mol}$ of D-glucose. The coupling constants of signals due to anomeric and methine protons and the chemical shifts of ${ }^{13} \mathrm{C}$-NMR signals ${ }^{7)}$ due to the sugar moiety indicated that all of the monosaccharide units were of the pyranose type; furthermore, the glycosidic linkage of the rhamnosyl unit was in the $\alpha$ mode in a ${ }^{1} \mathrm{C}_{4}$ conformation and those of the quinovosyl and glucosyl units were in the $\beta$ mode in a ${ }^{4} \mathrm{C}_{1}$ conformation. The ${ }^{13} \mathrm{C}$-NMR signals due to the sugar moiety of $\mathbf{6}$ were compared with those of methyl pyranosides in the literature. ${ }^{7,8)}$ Glycosylation
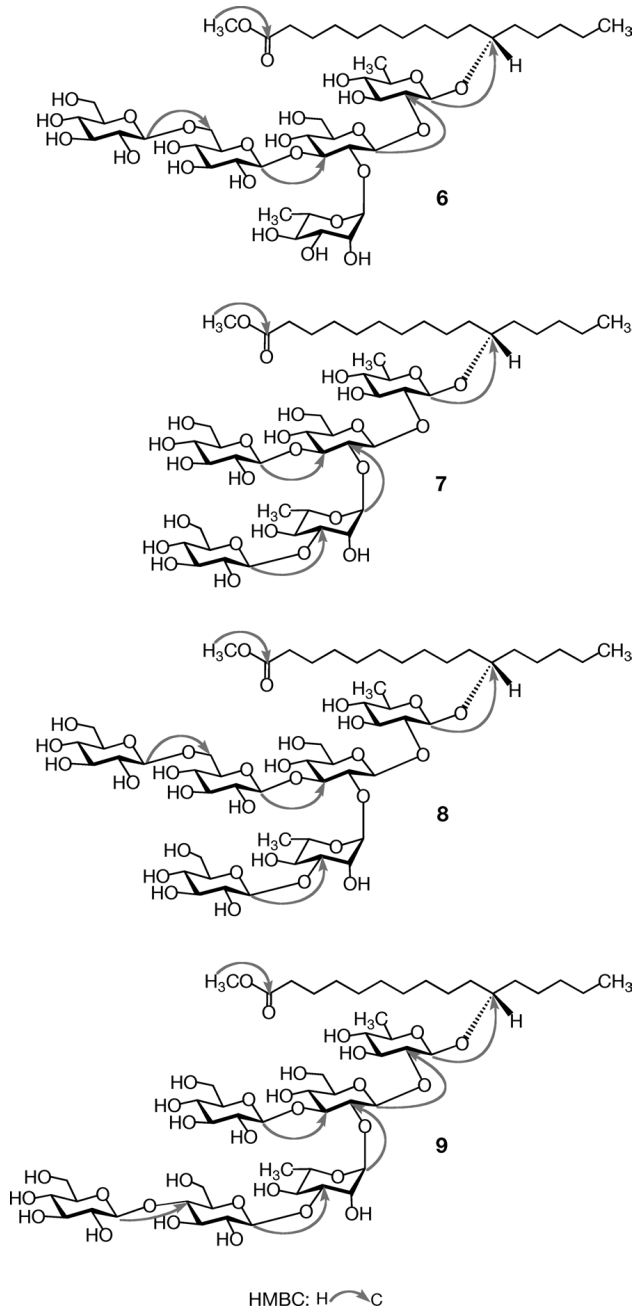

Fig. 3. ${ }^{1} \mathrm{H}-{ }^{13} \mathrm{C}$ Long-Range Correlations Observed for $\mathbf{6}-\mathbf{9}$ in the HMBC Spectra (in Pyridine- $d_{5}, 500 \mathrm{MHz}$ )

shifts $^{9,10)}$ were observed at C-2 $(+2.7 \mathrm{ppm})$ of the quinovosyl unit (Qui), C-2 (+3.1 ppm) and C-3 (+12.6 ppm) of the first glucosyl unit (Glc), and C-6 (+7.5 ppm) of the second glucosyl unit $\left(\mathrm{Glc}^{\prime}\right)$. Furthermore, the ${ }^{13} \mathrm{C}$-NMR signal assignable to $\mathrm{C}-11$ of $\mathrm{Agl}$ showed a downfield shift of $9.8 \mathrm{ppm}$ when compared with that of methyl $11 S$-jalapinolate. ${ }^{5)}$ These data suggest that the sugar linkages of $\mathbf{6}$ were located at $\mathrm{OH}-2$ of Qui, OH-2 and OH-3 of Glc, OH-6 of Glc', and OH-11 of Agl. The arrangement of sugar linkages was determined by using the heteronuclear multiple bond correlation (HMBC) spectrum of 6; that is, key cross peaks between H-1 of Qui and C-11 of Agl, H-1 of Glc and C-2 of Qui, H-1 of Glc' and C-3 of Glc, and H-1 of the third glucosyl unit (Glc") and C-6 of Glc' were observed (Fig. 3). Accordingly, the structure of 6a was characterized as $11 S$-jalapinolic acid $11-O-\alpha$-Lrhamnopyranosyl-( $1 \rightarrow 2)$ - $[O-\beta$-D-glucopyranosyl- $(1 \rightarrow 6)-O$ $\beta$-D-glucopyranosyl- $(1 \rightarrow 3)]-O$ - $\beta$-D-glucopyranosyl-( $(\rightarrow 2)$ $\beta$-D-quinovopyranoside (Fig. 1).

Compound 7a, named calysolic acid $\mathrm{B}$, was obtained as an amorphous powder. The ${ }^{1} \mathrm{H}$ - and ${ }^{13} \mathrm{C}-\mathrm{NMR}$ spectra of 7 , which were imposable on those of $\mathbf{6}$, indicated signals due to 1 mol each of $\beta$-D-quinovopyranosyl unit, $\alpha$-L-rhamnopyranosyl unit, and methyl $11 S$-jalapinolate unit and $3 \mathrm{~mol}$ of $\beta$-D-glucopyranosyl units. The negative-ion FAB-MS of $\mathbf{7 a}$ 
Table 1. $\quad{ }^{1} \mathrm{H}-\mathrm{NMR}$ Spectral Data for 5, 6, and 7 (in Pyridine- $d_{5}, 500 \mathrm{MHz}$ )

\begin{tabular}{|c|c|c|c|}
\hline & 5 & 6 & 7 \\
\hline Qui-1 & $4.89 \mathrm{~d}(7.5)$ & $4.88 \mathrm{~d}(8.0)$ & $4.90 \mathrm{~d}(7.5)$ \\
\hline 2 & $4.33 \mathrm{dd}(7.5,9.0)$ & $4.33 \mathrm{dd}(8.0,9.0)$ & $4.32 \mathrm{dd}(7.5,9.0)$ \\
\hline 3 & $4.41 \mathrm{dd}(9.0,9.0)$ & $4.42 \mathrm{dd}(9.0,9.0)$ & $4.48 \mathrm{dd}(9.0,9.0)$ \\
\hline 4 & $3.58 \mathrm{dd}(9.0,9.0)$ & $3.58 \mathrm{dd}(9.0,9.0)$ & $3.57 \mathrm{dd}(9.0,9.0)$ \\
\hline 5 & $3.73 \mathrm{~m}$ & $3.72 \mathrm{dq}(9.0,6.5)$ & ca. 3.75 \\
\hline 6 & $1.57 \mathrm{~d}(6.0)$ & $1.57 \mathrm{~d}(6.5)$ & $1.55 \mathrm{~d}(6.0)$ \\
\hline Glc-1 & $5.82 \mathrm{~d}(7.5)$ & $5.79 \mathrm{~d}(8.0)$ & $5.80 \mathrm{~d}(8.0)$ \\
\hline 2 & ca. 4.25 & ca. 4.20 & ca. 4.23 \\
\hline 3 & $4.07 \mathrm{dd}(9.0,9.0)$ & ca. 3.92 & $3.95 \mathrm{dd}(9.0,9.0)$ \\
\hline 4 & $4.03 \mathrm{dd}(9.0,9.0)$ & ca. 4.01 & ca. 3.99 \\
\hline 5 & 3.81 ddd $(2.5,6.0,9.0)$ & ca. 3.74 & ca. 3.76 \\
\hline $6 a$ & $4.37 \mathrm{dd}(2.5,12.0)$ & ca. 4.36 & $4.36 \mathrm{dd}(2.5,11.5)$ \\
\hline $6 b$ & $4.18 \mathrm{dd}(6.0,12.0)$ & ca. 4.20 & ca. 4.17 \\
\hline $\mathrm{Glc}^{\prime}-1$ & $5.00 \mathrm{~d}(7.5)$ & $4.86 \mathrm{~d}(8.0)$ & $4.94 \mathrm{~d}(7.5)$ \\
\hline 2 & ca. 4.01 & $3.96 \mathrm{dd}(8.0,9.0)$ & ca. 3.99 \\
\hline 3 & $4.14 \mathrm{dd}(9.0,9.0)$ & $4.10 \mathrm{dd}(9.0,9.0)$ & ca. 4.17 \\
\hline 4 & $4.09 \mathrm{dd}(9.0,9.0)$ & ca. 3.92 & ca. 4.07 \\
\hline 5 & ca. 4.01 & ca. 4.15 & ca. 3.99 \\
\hline $6 a$ & $4.54 \mathrm{dd}(2.5,11.0)$ & ca. 4.96 & $4.55 \mathrm{dd}(1.5,11.5)$ \\
\hline $6 \mathrm{~b}$ & ca. 4.25 & ca. 3.89 & ca. 4.23 \\
\hline Glc"-1 & & $4.79 \mathrm{~d}(8.0)$ & \\
\hline 2 & & ca. 4.01 & \\
\hline 3 & & ca. 4.20 & \\
\hline 4 & & $4.25 \mathrm{dd}(9.5,9.5)$ & \\
\hline 5 & & ca. 3.88 & \\
\hline $6 a$ & & 4.47 brd (10.5) & \\
\hline $6 \mathrm{~b}$ & & ca. 4.35 & \\
\hline Glc"'-1 & & & $5.44 \mathrm{~d}(7.5)$ \\
\hline 2 & & & ca. 4.07 \\
\hline 3 & & & ca. 4.17 \\
\hline 4 & & & ca. 4.07 \\
\hline 5 & & & ca. 3.99 \\
\hline $6 a$ & & & $4.43 \mathrm{dd}(1.5,11.5)$ \\
\hline $6 \mathrm{~b}$ & & & ca. 4.17 \\
\hline Rha-1 & $6.33 \mathrm{~d}(1.0)$ & $6.29 \mathrm{~s}$ & $6.36 \mathrm{~s}$ \\
\hline 2 & $4.82 \mathrm{dd}(1.0,3.5)$ & 4.80 br s & $5.06 \mathrm{~d}(3.0)$ \\
\hline 3 & $4.61 \mathrm{dd}(3.5,9.5)$ & $4.60 \mathrm{dd}(3.5,9.5)$ & $4.84 \mathrm{dd}(3.0,9.0)$ \\
\hline 4 & $4.28 \mathrm{dd}(9.5,9.5)$ & $4.27 \mathrm{dd}(9.5,9.5)$ & $4.50 \mathrm{dd}(9.0,9.0)$ \\
\hline 5 & $4.94 \mathrm{~m}$ & ca. 4.96 & ca. 5.04 \\
\hline 6 & $1.80 \mathrm{~d}(6.5)$ & $1.79 \mathrm{~d}(6.5)$ & $1.77(6.0)$ \\
\hline Agl-2 & $2.32 \mathrm{t}(7.5)$ & $2.32 \mathrm{t}(7.5)$ & $2.32 \mathrm{t}(7.5)$ \\
\hline 11 & $3.92 \mathrm{~m}$ & ca. 3.90 & $3.90 \mathrm{~m}$ \\
\hline 16 & $0.87 \mathrm{t}(7.0)$ & $0.87 \mathrm{t}(7.0)$ & $0.86 \mathrm{t}(7.0)$ \\
\hline $\mathrm{OCH}_{3}$ & $3.62 \mathrm{~s}$ & $3.62 \mathrm{~s}$ & $3.61 \mathrm{~s}$ \\
\hline
\end{tabular}

$\delta$ in ppm from tetramethylsilane (TMS) (coupling constants $(J)$ in $\mathrm{Hz}$ are given in parentheses).

was similar to that of $\mathbf{6 a}$, in which an $[\mathrm{M}-\mathrm{H}]^{-}$and fragment ion peaks were seen at $\mathrm{m} / \mathrm{z} 1049,887[1049-162]^{-}, 741$ $[887-146]^{-}, 725[887-162]^{-}, 579\left[^{2} 725-146\right]^{-}$, and 417 $[579-162]^{-}$(Fig. 2). The ${ }^{13} \mathrm{C}-\mathrm{NMR}$ spectral data of 7 indicated glycosylation shifts at C-2 $(+2.9 \mathrm{ppm})$ of Qui, C-2 $(+2.3 \mathrm{ppm})$ and $\mathrm{C}-3(+11.6 \mathrm{ppm})$ of Glc, C-3 (+10.6 ppm) of Rha, and C-11 (+9.8 ppm) of Agl. Based on the above data, 7 was considered to be a positional isomer of $\mathbf{6}$ in which the terminal glucopyranosyl unit was rearranged from OH-6 of Glc' to OH-3 of Rha. This was supported by the HMBC spectrum of 7, where correlations were observed between H-1 of Qui and C-11 of Agl, H-1 of Rha and C-2 of Glc, H-1 of Glc' and C-3 of Glc, and H-1 of the fourth glucosyl unit (Glc'"') and C-3 of Rha (Fig. 3). Consequently, the structure of $7 \mathbf{a}$ was concluded to be $11 S$-jalapinolic acid 11$O$ - $\beta$-D-glucopyranosyl-( $1 \rightarrow 3)-O$ - $\alpha$-L-rhamnopyranosyl$(1 \rightarrow 2)-[O-\beta$-D-glucopyranosyl- $(1 \rightarrow 3)]-O-\beta$-D-glucopyranosyl-(1 $\rightarrow 2$ )- $\beta$-D-quinovopyranoside (Fig. 1 ).
Compound 8a, named calysolic acid $\mathrm{C}$, was obtained as an amorphous powder. The negative-ion FAB-MS of 8a revealed an $[\mathrm{M}-\mathrm{H}]^{-}$ion peak at $\mathrm{m} / \mathrm{z} 1211$, which was 162 mass units larger than those of $\mathbf{6 a}$ and $\mathbf{7 a}$, and fragment ion peaks at $\mathrm{m} / \mathrm{z} 1049[1211-162]^{-}, 903[1211-146]^{-}, 887$ $[1049-162]^{-}, 725[887-162]^{-}, 579\left[^{2} 25-146\right]^{-}, 417$ $[579-162]^{-}$, and $271[417-146]^{-}$(Fig. 2). The ${ }^{1} \mathrm{H}-$ and ${ }^{13} \mathrm{C}-$ NMR spectra of 8 indicated that it was composed of $4 \mathrm{~mol}$ of $\beta$-D-glucopyranose and $1 \mathrm{~mol}$ each of $\beta$-D-quinovopyranose, $\alpha$-L-rhamnopyranose, and methyl $11 S$-jalapinolate (Tables 2 and 3). Glycosylation shifts in the ${ }^{13} \mathrm{C}-\mathrm{NMR}$ spectral data of 8 were observed at C-2 $(+2.8 \mathrm{ppm})$ of Qui, C-2 $(+2.1 \mathrm{ppm})$ and C-3 (+12.8 ppm) of Glc, C-3 (+10.7 ppm) of Rha, C-6 $(+7.6 \mathrm{ppm})$ of $\mathrm{Glc}^{\prime}$, and C-11 (+9.8 ppm) of Agl. In addition, the HMBC spectrum of $\mathbf{8}$ showed key cross peaks between $\mathrm{H}-1$ of Qui and C-11 of Agl, H-1 of Glc' and C-3 of Glc, H-1 of Glc" and C-6 of Glc', and H-1 of Glc"' and C-3 of Rha (Fig. 3). Thus, the structure of $\mathbf{8 a}$ was determined to be $11 S$-jalapinolic acid $11-O-\beta$-D-glucopyranosyl- $(1 \rightarrow 3)-O$ $\alpha$-L-rhamnopyranosyl-( $1 \rightarrow 2)$-[O- $\beta$-D-glucopyranosyl$(1 \rightarrow 6)-O$ - $\beta$-D-glucopyranosyl-( $1 \rightarrow 3)]-O$ - $\beta$-D-glucopyranosyl-(1 $\rightarrow 2)$ - $\beta$-D-quinovopyranoside (Fig. 1).

Compound 9a, named calysolic acid $\mathrm{D}$, was obtained as an amorphous powder and gave the same $[\mathrm{M}-\mathrm{H}]^{-}$ion peak as that of $\mathbf{8 a}$ and fragment ion peaks at $\mathrm{m} / \mathrm{z} 1211,1049,887$, $741,725,579$, and 417 (Fig. 2). The ${ }^{1} \mathrm{H}-$ and ${ }^{13} \mathrm{C}-\mathrm{NMR}$ spectral data of 9 indicated that it was composed of the same units as those of $\mathbf{8}$. In the ${ }^{13} \mathrm{C}-\mathrm{NMR}$ spectral data of $\mathbf{9}$, glycosylation shifts were observed at C-2 $(+3.0 \mathrm{ppm})$ of Qui, C-2 $(+2.1 \mathrm{ppm})$ and $\mathrm{C}-3(+11.6 \mathrm{ppm})$ of Glc, C-3 $(+11.0 \mathrm{ppm})$ of Rha, C-4 (+10.2 ppm) of Glc'"', and C-11 (+9.8 ppm) of Agl. These data show that for $\mathbf{9}$, one additional $\beta$-D-glucopyranosyl unit may be attached to $\mathrm{OH}-4$ of Glc" of 7. This was confirmed by the appearance of key cross peaks between $\mathrm{H}-1$ of Qui and C-11 of Agl, H-1 of Glc and C-2 of Qui, H-1 of Rha and C-2 of Glc, H-1 of Glc' and C-3 of Glc, H-1 of Glc'" and C-3 of Rha, and H-1 of the fifth glucosyl unit (Glc'"') and C-4 of Glc'" in the HMBC spectrum of 9 (Fig. 3). Therefore, the structure of $9 \mathrm{a}$ was defined as $11 S$-jalapinolic acid 11-O$\beta$-D-glucopyranosyl-( $(1 \rightarrow 4)-O$ - $\beta$-D-glucopyranosyl-( $1 \rightarrow 3)-O$ $\alpha$-L-rhamnopyranosyl-( $1 \rightarrow 2)$ - $[O-\beta$-D-glucopyranosyl$(1 \rightarrow 3)]-O-\beta$-D-glucopyranosyl-( $1 \rightarrow 2)-\beta$-D-quinovopyranoside (Fig. 1).

As the components of the resin glycoside fraction of $C$. soldanella, four new glycosidic acids, calysolic acids A, B, $\mathrm{C}$, and D, one known glycosidic acid, soldanellic acid B, and three organic acids, $2 S$-methylbutyric, tiglic, and $2 S, 3 S$-nilic acids were elucidated. The absolute configuration of nilic acid was different from those of the components of soldanellines A and B, and calysolic acid B was the component glycosidic acid of soldanelline A.

\section{Experimental}

General Procedure Optical rotations were performed with a JASCO DIP-1000 KYU digital polarimeter (JASCO, Tokyo, Japan). MS were recorded on a JEOL JMS-700 (JEOL, Tokyo, Japan). ${ }^{1} \mathrm{H}-$ and ${ }^{13} \mathrm{C}-\mathrm{NMR}$ spectra were recorded with a JEOL ECA-500 spectrometer (JEOL), and chemical shifts were given on a $\delta(\mathrm{ppm})$ scale with tetramethylsilane (TMS) as an internal standard. Silica gel 60 (Merck, Art. 1.09385; Merck, Darmstadt, Germany), Sephadex LH-20 (Pharmacia Fine Chemicals, Uppsala, Sweden), Chromatorex ODS (Fuji Silysia Chemical, Ltd., Aichi, Japan), and Diaion HP20 (Mitsubishi Chemical Industries Co., Ltd., Tokyo, Japan) were used for column chromatography. HPLC separation was run on a Shimadzu 
Table $2 .{ }^{13} \mathrm{C}$-NMR Spectral Data for 5-9 (in Pyridine- $d_{5}, 125 \mathrm{MHz}$ )

\begin{tabular}{|c|c|c|c|c|c|c|c|c|c|c|c|}
\hline & 5 & 6 & 7 & 8 & 9 & & 5 & 6 & 7 & 8 & 9 \\
\hline Qui-1 & 102.3 & 102.4 & 102.3 & 102.3 & 102.3 & Glc"'"'-1 & & & & & 104.9 \\
\hline 2 & 79.6 & 79.3 & 79.5 & 79.4 & 79.6 & 2 & & & & & 74.7 \\
\hline 3 & 79.1 & 79.1 & 79.1 & 79.2 & 79.1 & 3 & & & & & 78.3 \\
\hline 4 & 77.0 & 77.0 & 77.0 & 77.1 & 77.1 & 4 & & & & & 71.5 \\
\hline 5 & 72.5 & 72.6 & 72.5 & 72.5 & 72.5 & 5 & & & & & 78.5 \\
\hline 6 & 18.5 & 18.5 & 18.5 & 18.5 & 18.5 & 6 & & & & & 62.4 \\
\hline Glc-1 & 101.7 & 101.5 & 101.7 & 101.5 & 101.6 & Rha-1 & 102.2 & 102.1 & 101.8 & 101.9 & 101.8 \\
\hline 2 & 77.8 & 77.9 & 77.1 & 76.9 & 76.9 & 2 & 72.3 & 72.2 & 71.7 & 71.7 & 71.7 \\
\hline 3 & 89.3 & 90.7 & 89.7 & 90.9 & 89.7 & 3 & 72.6 & 72.5 & 83.1 & 83.2 & 83.5 \\
\hline 4 & 70.1 & 70.3 & 70.3 & 70.3 & 70.2 & 4 & 74.3 & 74.3 & 73.2 & 73.2 & 73.2 \\
\hline 5 & 77.4 & 76.9 & 77.4 & 77.0 & 77.4 & 5 & 69.6 & 69.5 & 69.3 & 69.3 & 69.2 \\
\hline 6 & 62.9 & 62.5 & 63.0 & 62.5 & 62.9 & 6 & 19.0 & 19.0 & 18.9 & 19.0 & 18.9 \\
\hline $\mathrm{Glc}^{\prime}-1$ & 104.5 & 105.1 & 104.6 & 105.2 & 104.6 & Agl-1 & 174.0 & 174.0 & 174.0 & 174.0 & 174.0 \\
\hline 2 & 74.9 & 74.5 & 74.9 & 74.5 & 74.8 & 2 & 34.2 & 34.2 & 34.2 & 34.2 & 34.1 \\
\hline 3 & 78.6 & 78.4 & 78.6 & 78.3 & 78.4 & 11 & 80.7 & 80.8 & 80.8 & 80.8 & 80.8 \\
\hline 4 & 71.5 & 71.8 & 71.5 & 71.9 & 71.5 & 16 & 14.3 & 14.3 & 14.3 & 14.3 & 14.2 \\
\hline 5 & 78.6 & 76.4 & 78.6 & 76.4 & 78.5 & $\mathrm{OCH}_{3}$ & 51.2 & 51.2 & 51.2 & 51.2 & 51.2 \\
\hline 6 & 62.4 & 70.0 & 62.4 & 70.1 & 62.4 & $\mathrm{CH}_{2}$ & 35.3 & 35.3 & 35.3 & 35.3 & 35.3 \\
\hline Glc"-1 & & 104.4 & & 104.4 & & $\mathrm{CH}_{2}^{2}$ & 34.9 & 34.9 & 34.8 & 34.9 & 34.8 \\
\hline 2 & & 75.6 & & 75.6 & & $\mathrm{CH}_{2}$ & 32.3 & 32.2 & 32.3 & 32.3 & 32.2 \\
\hline 3 & & 77.5 & & 77.9 & & $\mathrm{CH}_{2}$ & 30.5 & 30.5 & 30.5 & 30.5 & 30.4 \\
\hline 4 & & 71.3 & & 71.3 & & $\mathrm{CH}_{2}$ & 30.1 & 30.1 & 30.1 & 30.1 & 30.1 \\
\hline 5 & & 78.4 & & 78.5 & & $\mathrm{CH}_{2}$ & 29.9 & 29.9 & 29.9 & 29.9 & 29.9 \\
\hline 6 & & 62.5 & & 62.5 & & $\mathrm{CH}_{2}$ & 29.6 & 29.6 & 29.6 & 29.6 & 29.6 \\
\hline Glc"'-1 & & & 106.2 & 106.1 & 106.0 & $\mathrm{CH}_{2}^{2}$ & 29.4 & 29.4 & 29.4 & 29.4 & 29.4 \\
\hline 2 & & & 76.0 & 76.0 & 75.5 & $\mathrm{CH}_{2}$ & 25.4 & 25.4 & 25.3 & 25.3 & 25.3 \\
\hline 3 & & & 78.3 & 78.5 & 76.4 & $\mathrm{CH}_{2}$ & 25.3 & 25.3 & 25.3 & 25.3 & 25.3 \\
\hline 4 & & & 71.8 & 71.9 & 81.6 & $\mathrm{CH}_{2}$ & 25.2 & 25.2 & 25.3 & 25.3 & 25.2 \\
\hline 5 & & & 78.1 & 78.1 & 76.2 & $\mathrm{CH}_{2}^{2}$ & 23.0 & 22.9 & 22.9 & 23.0 & 22.9 \\
\hline 6 & & & 62.7 & 62.8 & 62.0 & & & & & & \\
\hline
\end{tabular}

$\delta$ in ppm from TMS.

Table 3. ${ }^{1} \mathrm{H}-\mathrm{NMR}$ Spectral Data for 8 and 9 (in Pyridine- $d_{5}, 500 \mathrm{MHz}$ )

\begin{tabular}{|c|c|c|c|c|c|}
\hline & 8 & 9 & & 8 & 9 \\
\hline Qui-1 & $4.89 \mathrm{~d}(8.0)$ & $4.90 \mathrm{~d}(7.5)$ & Glc"'-1 & $5.43 \mathrm{~d}(7.5)$ & $5.40 \mathrm{~d}(8.0)$ \\
\hline 2 & $4.32 \mathrm{dd}(8.0,9.0)$ & $4.33 \mathrm{dd}(7.5,9.0)$ & 2 & $4.07 \mathrm{~d}(7.5,9.0)$ & ca. 4.07 \\
\hline 3 & $4.48 \mathrm{dd}(9.0,9.0)$ & $4.47 \mathrm{dd}(9.0,9.0)$ & 3 & ca. 4.18 & ca. 4.19 \\
\hline 4 & $3.57 \mathrm{dd}(9.0,9.0)$ & 3.58 dd $(9.0,9.0)$ & 4 & $4.06 \mathrm{dd}(9.0,9.0)$ & ca. 4.18 \\
\hline 5 & ca. 3.75 & ca. 3.76 & 5 & 3.99 dd $(9.0,9.0)$ & ca. 3.98 \\
\hline 6 & $1.56 \mathrm{~d}(6.0)$ & $1.55 \mathrm{~d}(6.0)$ & $6 a$ & $4.42 \mathrm{dd}(2.5,11.0)$ & ca. 4.38 \\
\hline Glc-1 & $5.76 \mathrm{~d}(7.5)$ & $5.79 \mathrm{~d}(7.5)$ & $6 b$ & ca. 4.14 & ca. 4.33 \\
\hline 2 & ca. 4.16 & $4.22 \mathrm{dd}(7.5,9.0)$ & Glc ${ }^{\prime \prime \prime \prime}-1$ & & $5.08 \mathrm{~d}(8.0)$ \\
\hline 3 & 3.77 dd $(9.0,9.0)$ & 3.91 dd $(9.0,9.0)$ & 2 & & ca. 4.01 \\
\hline 4 & $3.97 \mathrm{dd}(9.0,9.0)$ & ca. 3.96 & 3 & & ca. 4.19 \\
\hline 5 & 3.69 ddd $(3.0,6.0,9.0)$ & ca. 3.76 & 4 & & ca. 4.16 \\
\hline $6 a$ & ca. 4.35 & ca. 4.36 & 5 & & ca. 4.00 \\
\hline $6 b$ & ca. 4.20 & ca. 4.13 & $6 a$ & & ca. 4.51 \\
\hline Glc'-1 & $4.80 \mathrm{~d}(7.5)$ & $4.90 \mathrm{~d}(7.5)$ & $6 b$ & & ca. 4.25 \\
\hline 2 & $3.95 \mathrm{dd}(7.5,9.0)$ & ca. 3.96 & Rha-1 & $6.31 \mathrm{~s}$ & $6.36 \mathrm{~d}(1.5)$ \\
\hline 3 & ca. 4.26 & ca. 4.16 & 2 & ca. 5.05 & $5.02 \mathrm{dd}(1.5,3.0)$ \\
\hline 4 & ca. 3.88 & ca. 4.06 & 3 & $4.82 \mathrm{dd}(4.0,9.5)$ & $4.80 \mathrm{dd}(3.0,9.0)$ \\
\hline 5 & ca. 4.26 & ca. 3.96 & 4 & $4.49 \mathrm{dd}(9.5,9.5)$ & ca. 4.50 \\
\hline $6 a$ & 4.99 br d (10.0) & $4.54 \mathrm{dd}(2.5,11.5)$ & 5 & ca. 5.04 & $5.06 \mathrm{~m}$ \\
\hline $6 b$ & 3.85 br d $(10.0)$ & ca. 4.22 & 6 & $1.76 \mathrm{~d}(6.5)$ & $1.77 \mathrm{~d}(6.0)$ \\
\hline Glc"-1 & $4.76 \mathrm{~d}(7.5)$ & & Agl-2 & $2.32 \mathrm{t}(7.5)$ & $2.31 \mathrm{t}(7.5)$ \\
\hline 2 & $4.01 \mathrm{dd}(7.5,9.0)$ & & 11 & ca. 3.88 & ca. 3.91 \\
\hline 3 & ca. 4.26 & & 16 & $0.86 \mathrm{t}(7.0)$ & $0.86 \mathrm{t}(7.0)$ \\
\hline 4 & $4.25 \mathrm{dd}(9.0,9.0)$ & & $\mathrm{OCH}_{3}$ & $3.62 \mathrm{~s}$ & $3.62 \mathrm{~s}$ \\
\hline 5 & ca. 3.86 & & & & \\
\hline $6 a$ & ca. 4.48 & & & & \\
\hline $6 b$ & ca. 4.35 & & & & \\
\hline
\end{tabular}

$\delta$ in ppm from TMS (coupling constants $(J)$ in $\mathrm{Hz}$ are given in parentheses). 
LC-10AS micro pump (Shimadzu, Kyoto, Japan) with a Shimadzu RID-6A RI-detector (Shimadzu). For HPLC column chromatography, Kusano C.I.G. prepacked Si-gel (Kusano Kagakukiki Co., Tokyo, Japan, $22 \mathrm{~mm}$ i.d. $\times 100 \mathrm{~mm}$, column 1), Kusano C.I.G. prepacked Si-gel (Kusano Kagakukiki Co., $22 \mathrm{~mm}$ i.d. $\times 300 \mathrm{~mm}$, column 2), and COSMOSIL 5C18-AR-II(Nacalai Tesque, Inc., Kyoto, Japan, $20 \mathrm{~mm}$ i.d. $\times 250 \mathrm{~mm}$, column 3) were used.

Plant Material The flesh leaves, stems, and roots of $C$. soldanella were collected in Mie prefecture, Japan, in May 2009, and identified by one of authors (H. Setoguchi). A voucher specimen has been deposited at the laboratory of Natural Products Chemistry, School of Agriculture, Tokai University.

Extarction and Preparation of the Crude Resin Glycoside Fraction The cut fresh leaves, stems, and roots of C. soldanella (916.9 g) were extracted with $\mathrm{MeOH}$ (101) at room temperature for 1 month, and the solvent was removed in vacuo to yield a $\mathrm{MeOH}$ extract $(126.9 \mathrm{~g})$. The $\mathrm{MeOH}$ extract was suspended in $\mathrm{H}_{2} \mathrm{O}$ (3.51) and then successively extracted with EtOAc (1.61) and $\mathrm{BuOH}(0.61)$ to afford an EtOAc-soluble fraction (fr.) $(48.57 \mathrm{~g})$ and a $\mathrm{BuOH}$-soluble fr. $(8.15 \mathrm{~g})$. A part $(1.70 \mathrm{~g})$ of the EtOAc-soluble fr. was applied to Sephadex LH-20 column chromatography $(\mathrm{MeOH})$ to give a crude resin glycoside fr. $(1.03 \mathrm{~g})$.

Alkaline Hydrolysis of the Crude Resin Glycoside Fraction A part $(912 \mathrm{mg})$ of the crude resin glycoside fr. was dissolved in $1 \mathrm{~m} \mathrm{KOH}(10 \mathrm{ml})$ and heated at $95{ }^{\circ} \mathrm{C}$ for $1 \mathrm{~h}$. After cooling, the reaction mixture was adjusted to $\mathrm{pH} 4$ with $1 \mathrm{M} \mathrm{HCl}$ and shaken with ether $(30 \mathrm{ml} \times 4)$. The ether layer was dried over $\mathrm{MgSO}_{4}$ and evaporated in vacuo to give an oil (organic acid fr., $63 \mathrm{mg}$ ). The $\mathrm{H}_{2} \mathrm{O}$ layer was chromatographed over MCI gel CHP20 (solvent, $\mathrm{H}_{2} \mathrm{O} \rightarrow$ acetone). The acetone eluate was evaporated to dryness to afford an amorphous powder (654 mg, glycosidic acid fr.).

Identification of Organic Acids The organic acid fr. $(63 \mathrm{mg})$ in acetone $(20 \mathrm{ml})$ was neutralized with triethylamine, and then the solvent was removed. A mixture of the residue and $p$-bromophenacyl bromide $(300 \mathrm{mg})$ in acetone $(20 \mathrm{ml})$ was left to stand at room temperature for $1 \mathrm{~h}$ and then concentrated in vacuo to give a residue. The residue was subjected to HPLC [column 1; solvent, hexane-acetone $(3: 1)]$ to give fractions (frs.) $1-4, p$ bromophenacyl tiglate $(\mathbf{2}, 20 \mathrm{mg})$, and $p$-bromophenacyl $2 S, 3 S$-nilate $(3$, $7 \mathrm{mg})$. HPLC [column 1; solvent, hexane-AcOEt $(50: 1)]$ of fr. $2(48 \mathrm{mg})$ gave $p$-bromophenacyl $2 S$-methylbutyrate $(\mathbf{1}, 9 \mathrm{mg})$.

1: Amorphous powder, $[\alpha]_{\mathrm{D}}^{31}+9.4^{\circ}\left(c=1.2, \mathrm{CHCl}_{3}\right)$. ${ }^{1} \mathrm{H}-\mathrm{NMR}$ spectral data (in $\left.\mathrm{CDCl}_{3}, 500 \mathrm{MHz}\right) \delta: 0.98\left(3 \mathrm{H}, \mathrm{dd}, J=7.5,7.5 \mathrm{~Hz}, \mathrm{H}_{3}-4\right), 1.24(3 \mathrm{H}$, d, $\left.J=7.0 \mathrm{~Hz}, \mathrm{H}_{3}-5\right), 1.56(1 \mathrm{H}$, ddq, $J=14.0,7.0,7.5 \mathrm{~Hz}, \mathrm{Ha}-3), 1.79(1 \mathrm{H}$, ddq, $J=14.0,7.0,7.5 \mathrm{~Hz}, \mathrm{Hb}-3), 2.56(1 \mathrm{H}, \mathrm{ddq}, J=7.0,7.0,7.0 \mathrm{~Hz}, \mathrm{H}-2)$, $5.28\left(2 \mathrm{H}, \mathrm{s}, \mathrm{OCH}_{2} \mathrm{CO}\right), 7.64(2 \mathrm{H}, \mathrm{d}-\mathrm{like}, J=8.5 \mathrm{~Hz}$, aromatic $\mathrm{H}), 7.78(2 \mathrm{H}$, d-like, $J=8.5 \mathrm{~Hz}$, aromatic $\mathrm{H}$ ).

2: Amorphous powder. ${ }^{1} \mathrm{H}-\mathrm{NMR}$ spectral data (in $\mathrm{CDCl}_{3}, 500 \mathrm{MHz}$ ) $\delta$ : $1.84\left(3 \mathrm{H}, \mathrm{d}, J=7.0 \mathrm{~Hz}, \mathrm{H}_{3}-4\right), 1.90\left(3 \mathrm{H}, \mathrm{d}, J=1.5 \mathrm{~Hz}, \mathrm{H}_{3}-5\right), 5.35(2 \mathrm{H}, \mathrm{s}$, $\left.\mathrm{OCH}_{2} \mathrm{CO}\right), 7.04(1 \mathrm{H}, \mathrm{qq}, J=7.0,1.5 \mathrm{~Hz}, \mathrm{H}-3), 7.64(2 \mathrm{H}, \mathrm{d}-$ like, $J=8.5 \mathrm{~Hz}$, aromatic $\mathrm{H}), 7.80(2 \mathrm{H}$, d-like, $J=8.5 \mathrm{~Hz}$, aromatic $\mathrm{H})$.

3: Amorphous powder, $[\alpha]_{\mathrm{D}}^{31}+13.5^{\circ}\left(c=1.0, \mathrm{CHCl}_{3}\right) \cdot{ }^{1} \mathrm{H}-\mathrm{NMR}$ spectral data (in $\left.\mathrm{CDCl}_{3}, 500 \mathrm{MHz}\right) \delta: 1.25\left(3 \mathrm{H}, \mathrm{d}, J=7.0 \mathrm{~Hz}, \mathrm{H}_{3}-5\right), 1.30(3 \mathrm{H}, \mathrm{d}$, $\left.J=6.5 \mathrm{~Hz}, \mathrm{H}_{3}-4\right), 2.63(1 \mathrm{H}, \mathrm{dq}, J=6.5,7.0 \mathrm{~Hz}, \mathrm{H}-2), 3.97(1 \mathrm{H}, \mathrm{m}, \mathrm{H}-3), 5.34$ $\left(1 \mathrm{H}, \mathrm{d}, J=16.0 \mathrm{~Hz}, \mathrm{OCH}_{2} \mathrm{CO}\right), 5.44\left(1 \mathrm{H}, \mathrm{d}, J=16.0 \mathrm{~Hz}, \mathrm{OCH}_{2} \mathrm{CO}\right), 7.65$ $(2 \mathrm{H}, \mathrm{d}$-like, $J=8.5 \mathrm{~Hz}$, aromatic $\mathrm{H}), 7.79(2 \mathrm{H}, \mathrm{d}$-like, $J=8.5 \mathrm{~Hz}$, aromatic $\mathrm{H})$.

Acidic Hydrolysis of the Glycosidic Acid Fraction A part (100 mg) of the glycosidic acid fr. in $1 \mathrm{M} \mathrm{HCl}(2 \mathrm{ml})$ was heated at $95^{\circ} \mathrm{C}$ for $1 \mathrm{~h}$. The reaction mixture was diluted with $\mathrm{H}_{2} \mathrm{O}(5 \mathrm{ml})$ and then extracted with ether $(5 \mathrm{ml} \times 6)$. The ether extract was dried over $\mathrm{MgSO}_{4}$ and concentrated in vacuo to give a residue $(15 \mathrm{mg})$. Treatment of the residue with trimethylsilyldiazomethane-hexane, followed by evaporation, gave a powder, which was chromatographed over a silica gel column [solvent, hexane-EtOAc $(10: 1 \rightarrow$ $5: 1 \rightarrow 2: 1 \rightarrow 1: 1)]$ to afford methyl jalapinoate $(4,5 \mathrm{mg})$.

4: Amorphous powder. ${ }^{1} \mathrm{H}-\mathrm{NMR}$ spectral data (in $\left.\mathrm{CDCl}_{3}, 500 \mathrm{MHz}\right) \delta$ : $0.89\left(3 \mathrm{H}, \mathrm{t}, J=7.0 \mathrm{~Hz}, \mathrm{H}_{3}-16\right), 2.30\left(2 \mathrm{H}, \mathrm{t}, J=7.5 \mathrm{~Hz}, \mathrm{H}_{2}-2\right), 3.59(1 \mathrm{H}, \mathrm{m}, \mathrm{H}-$ 11), $3.67\left(3 \mathrm{H}, \mathrm{s}, \mathrm{OCH}_{3}\right) \cdot{ }^{13} \mathrm{C}-\mathrm{NMR}$ (in $\left.\mathrm{CDCl}_{3}, 125 \mathrm{MHz}\right) \delta: 14.1(\mathrm{C}-16$ ), $22.7,24.9,25.3,25.6,29.1,29.2,29.4,29.5,29.7,31.9,34.1,37.4(\times 2)$, $51.4\left(\mathrm{OCH}_{3}\right), 72.0(\mathrm{C}-11), 174.4(\mathrm{C}-1)$.

The aqueous layer was neutralized with Amberlite MB-3 (Organo Co., Tokyo) and then evaporated in vacuo to give a monosaccharide fr. This fr. was subjected to HPLC [condition 1: column, Shodex RS-Pac DC-613 (Showa Denko, Tokyo, $150 \mathrm{~mm} \times 6.0 \mathrm{~mm}$ ); solvent, $\mathrm{CH}_{3} \mathrm{CN}-\mathrm{H}_{2} \mathrm{O}$ (3:1); flow rate, $1.0 \mathrm{ml} / \mathrm{min}$; column temperature, $70^{\circ} \mathrm{C}$ ] using a Shimadzu RID10A (Shimadzu) detector to give three monosaccharides, which were analyzed by HPLC under condition 1 using a JASCO OR-2090 plus (JASCO) detector. The retention time $\left(t_{\mathrm{R}}\right)$ and optical activity of each of the monosaccharides were detected to be as follows. L-Rhamnose $\left[t_{\mathrm{R}}(\mathrm{min}) 3.6\right.$; optical activity, negative], D-quinovose [ $t_{\mathrm{R}}(\mathrm{min}) 4.1$; optical activity, positive], and D-glucose $\left[t_{\mathrm{R}}(\mathrm{min}) 7.2\right.$; optical activity, positive].

Preparation of (+)-MTPA Esters of 3 and 4 (+)-MTPACl $(15 \mathrm{mg})$ was added to individual solutions of $3(2 \mathrm{mg})$ and $4(2 \mathrm{mg})$ in pyridine $(0.5 \mathrm{ml})$ and $\mathrm{CCl}_{4}(5$ drops $)$ and left to stand at room temperature overnight. The solvent was removed under an $\mathrm{N}_{2}$ stream to give a residue. The residue was purified by chromatography over a silica gel column [solvent, hexaneEtOAc $(10: 1 \rightarrow 8: 1 \rightarrow 6: 1 \rightarrow 1: 1)]$ to give $(+)$-MTPA ester (3a, $2 \mathrm{mg})$ from 3 and (+)-MTPA ester $(\mathbf{4 a}, 2 \mathrm{mg})$ from 4 , respectively.

3a: Syrup. HR-positive-ion FAB-MS $m / z: 553.0435[\mathrm{M}+\mathrm{Na}]^{+}$(Calcd for $\mathrm{C}_{23} \mathrm{H}_{22} \mathrm{O}_{6}{ }^{79} \mathrm{BrF}_{3} \mathrm{Na}$ : 553.0449). ${ }^{1} \mathrm{H}-\mathrm{NMR}$ spectral data (in $\mathrm{CDCl}_{3}, 500 \mathrm{MHz}$ ) $\delta: 1.245\left(3 \mathrm{H}, \mathrm{d}, J=7.5 \mathrm{~Hz}, \mathrm{H}_{3}-5\right), 1.438\left(3 \mathrm{H}, \mathrm{d}, J=6.5 \mathrm{~Hz}, \mathrm{H}_{3}-4\right), 2.932(1 \mathrm{H}$, $\mathrm{dq}, J=7.5,7.5 \mathrm{~Hz}, \mathrm{H}-2), 3.556\left(3 \mathrm{H}, \mathrm{s}, \mathrm{OCH}_{3}\right), 5.053(1 \mathrm{H}, \mathrm{d}, J=16.0 \mathrm{~Hz}$, $\left.\mathrm{OCH}_{2} \mathrm{CO}\right), 5.125\left(1 \mathrm{H}, \mathrm{d}, J=16.0 \mathrm{~Hz}, \mathrm{OCH}_{2} \mathrm{CO}\right), 5.458(1 \mathrm{H}, \mathrm{dq}, J=7.5$, $6.5 \mathrm{~Hz}, \mathrm{H}-3), c a .7 .405(3 \mathrm{H}), c a .7 .543(2 \mathrm{H}), 7.641(2 \mathrm{H}, \mathrm{d}-\mathrm{like}, J=8.5 \mathrm{~Hz})$, $7.717(2 \mathrm{H}, \mathrm{d}-\mathrm{like}, J=8.5 \mathrm{~Hz})$.

4a: Syrup. HR-positive-ion FAB-MS $m / z: 525.2804[\mathrm{M}+\mathrm{Na}]^{+}$(Calcd for $\mathrm{C}_{27} \mathrm{H}_{41} \mathrm{O}_{5} \mathrm{~F}_{3} \mathrm{Na}$ : 525.2804). ${ }^{1} \mathrm{H}-\mathrm{NMR}$ spectral data (in $\left.\mathrm{CDCl}_{3}, 500 \mathrm{MHz}\right) \delta$ : $0.877\left(3 \mathrm{H}, \mathrm{t}, J=6.5 \mathrm{~Hz}, \mathrm{H}_{3}-16\right), 2.303\left(2 \mathrm{H}, \mathrm{t}, J=7.5 \mathrm{~Hz}, \mathrm{H}_{2}-2\right), 3.561(3 \mathrm{H}, \mathrm{s}$, $\left.\mathrm{OCH}_{3}\right), 3.669\left(3 \mathrm{H}, \mathrm{s}, \mathrm{OCH}_{3}\right), 5.084(1 \mathrm{H}, \mathrm{m}, \mathrm{H}-11), c a .7 .389(3 \mathrm{H}), c a .7 .545$ $(2 \mathrm{H})$.

Isolation of 5-9 A part $(554 \mathrm{mg})$ of the glycosidic acid fr. in $\mathrm{MeOH}$ $(30 \mathrm{ml})$ was methylated with trimethylsilyldiazomethane-hexane. The concentrated reaction mixture was subjected to HPLC (column 3; solvent, $85 \%$ $\mathrm{MeOH}$ ) to afford frs. 5-8. HPLC [column 2; solvent, $\mathrm{CHCl}_{3}-\mathrm{MeOH}-\mathrm{H}_{2} \mathrm{O}$ $(10: 2: 0.1 \rightarrow 8: 2: 0.2 \rightarrow 6: 4: 1)]$ of fr. $6(90 \mathrm{mg})$ gave $6(11 \mathrm{mg})$ and 8 $(12 \mathrm{mg})$. Fr. $7(112 \mathrm{mg})$ was subjected to HPLC [column 2; solvent, $\left.\mathrm{CHCl}_{3}-\mathrm{MeOH}-\mathrm{H}_{2} \mathrm{O}(14: 2: 0.1 \rightarrow 10: 2: 0.1 \rightarrow 8: 2: 0.2 \rightarrow 6: 4: 1)\right]$ to afford $9(25 \mathrm{mg})$ and frs. 7.1-7.5. Fr. $7.3(36 \mathrm{mg})$ and fr. $7.4(22 \mathrm{mg})$ were each chromatographed over a silica gel column [solvent, $\mathrm{CHCl}_{3}-\mathrm{MeOH}-\mathrm{H}_{2} \mathrm{O}$ $(14: 2: 0.1 \rightarrow 10: 2: 0.1 \rightarrow 8: 2: 0.2 \rightarrow 6: 4: 1)]$ to give $5(8 \mathrm{mg})$ and $7(12 \mathrm{mg})$ from fr. 7.3 and $7(9 \mathrm{mg})$ from fr. 7.4 .

5: Amorphous powder, $[\alpha]_{\mathrm{D}}^{25}-41.9^{\circ}(c=1.6, \mathrm{MeOH}) .{ }^{1} \mathrm{H}-$ and ${ }^{13} \mathrm{C}-\mathrm{NMR}$ spectral data: see Tables 1 and 2 .

6: Amorphous powder, $[\alpha]_{\mathrm{D}}^{25}-41.9^{\circ}(c=2.5, \mathrm{MeOH}) .{ }^{1} \mathrm{H}-$ and ${ }^{13} \mathrm{C}-\mathrm{NMR}$ spectral data: see Tables 1 and 2 .

7: Amorphous powder, $[\alpha]_{\mathrm{D}}^{25}-29.8^{\circ}(c=0.4, \mathrm{MeOH}) .{ }^{1} \mathrm{H}-$ and ${ }^{13} \mathrm{C}-\mathrm{NMR}$ spectral data: see Tables 1 and 2 .

8: Amorphous powder, $[\alpha]_{\mathrm{D}}^{25}-40.1^{\circ}(c=1.0, \mathrm{MeOH}) .{ }^{1} \mathrm{H}-$ and ${ }^{13} \mathrm{C}-\mathrm{NMR}$ spectral data: see Tables 2 and 3 .

9: Amorphous powder, $[\alpha]_{\mathrm{D}}^{25}-28.4^{\circ}(c=0.5, \mathrm{MeOH}) .{ }^{1} \mathrm{H}-$ and ${ }^{13} \mathrm{C}-\mathrm{NMR}$ spectral data: see Tables 2 and 3 .

Preparation of 5a-9a Compounds $5(10 \mathrm{mg}), 6(10 \mathrm{mg}), 7(6 \mathrm{mg}), 8$ $(7 \mathrm{mg})$, and $9(3 \mathrm{mg})$ were each heated with $1 \mathrm{M} \mathrm{KOH}(1 \mathrm{ml})$ at $95^{\circ} \mathrm{C}$ for $30 \mathrm{~min}$. After cooling, the mixture was acidified $(\mathrm{pH} 3)$ with $1 \mathrm{M} \mathrm{HCl}$ and desalted by using chromatography over MCI gel CHP 20 (solvent, $\mathrm{H}_{2} \mathrm{O} \rightarrow$ acetone) to give soldanellic acid B $(\mathbf{5 a}, 8 \mathrm{mg})$ from $\mathbf{5}$, calysolic acid A (6a, $8 \mathrm{mg}$ ) from $\mathbf{6}$, calysolic acid B (7a, $3 \mathrm{mg})$ from $\mathbf{7}$, calysolic acid C $(\mathbf{8 a}, 4 \mathrm{mg})$ from 8 , and calysolic acid D $(9 \mathrm{a}, 2 \mathrm{mg})$ from 9 , respectively.

5a: Amorphous powder. Negative-ion FAB-MS $m / z: 887[\mathrm{M}-\mathrm{H}]^{-}, 741$ $[887-146]^{-}, 725[887-162]^{-}, 579[725-146]^{-}, 417\left[^{5} 579-162\right]^{-}, 271$ $[417-146]^{-}$. The ${ }^{1} \mathrm{H}-\mathrm{NMR}$ spectral data were superimposable on those of soldanellic acid B. ${ }^{3)}$

6a: Amorphous powder. Negative-ion FAB-MS m/z: $1049[\mathrm{M}-\mathrm{H}]^{-}, 903$ $[1049-146]^{-}, 887[1049-162]^{-}, 725[887-162]^{-}, 579\left[^{2725-146}\right]^{-}, 417$ $[579-162]^{-}, 271[417-146]^{-}$. HR-negative-ion FAB-MS $m / z: 1049.5028$ (Calcd for $\mathrm{C}_{46} \mathrm{H}_{81} \mathrm{O}_{26}: 1049.5016$ ). ${ }^{1} \mathrm{H}-\mathrm{NMR}$ (in pyridine- $\left.d_{5}, 500 \mathrm{MHz}\right) \delta$ : $0.86\left(3 \mathrm{H}, \mathrm{t}, J=7.0 \mathrm{~Hz}, \mathrm{H}_{3}-16\right.$ of Agl), $1.57\left(3 \mathrm{H}, \mathrm{d}, J=6.0 \mathrm{~Hz}, \mathrm{H}_{3}-6\right.$ of Qui), $1.77\left(3 \mathrm{H}, \mathrm{d}, J=6.0 \mathrm{~Hz}, \mathrm{H}_{3}-6\right.$ of Rha), $2.50\left(2 \mathrm{H}, \mathrm{t}, J=7.5 \mathrm{~Hz}, \mathrm{H}_{2}-2\right.$ of Agl), $3.57(1 \mathrm{H}, \mathrm{dd}, J=9.0,9.0 \mathrm{~Hz}, \mathrm{H}-4$ of Qui), $4.45(1 \mathrm{H}, \mathrm{brd}, J=10.5 \mathrm{~Hz}, \mathrm{Hb}-6$ of $\left.\mathrm{Glc}^{\prime \prime}\right), 4.60(1 \mathrm{H}, \mathrm{dd}, J=3.0,9.0 \mathrm{~Hz}, \mathrm{H}-3$ of Rha $), 4.77(1 \mathrm{H}, \mathrm{d}, J=8.0 \mathrm{~Hz}$, $\mathrm{H}-1$ of $\left.\mathrm{Glc}^{\prime \prime}\right), 4.79(1 \mathrm{H}$, br s, H-2 of Rha), $4.83(1 \mathrm{H}, \mathrm{d}, J=7.5 \mathrm{~Hz}, \mathrm{H}-1$ of $\left.\mathrm{Glc}^{\prime}\right), 4.85(1 \mathrm{H}, \mathrm{d}, J=7.5 \mathrm{~Hz}, \mathrm{H}-1$ of Qui), $5.73(1 \mathrm{H}, \mathrm{d}, J=7.5 \mathrm{~Hz}, \mathrm{H}-1$ of Glc), $6.22\left(1 \mathrm{H}, \mathrm{s}, \mathrm{H}-1\right.$ of Rha). ${ }^{13} \mathrm{C}-\mathrm{NMR}$ (in pyridine- $\left.d_{5}, 125 \mathrm{MHz}\right) \delta: 177.1$ (C-1 of Agl), 105.1 (C-1 of Glc'), 104.4 (C-1 of Glc"), 102.4 (C-1 of Qui), 102.2 (C-1 of Rha), 101.6 (C-1 of Glc), 90.6 (C-3 of Glc), 80.9 (C-11 of $\mathrm{Agl}$ ), 79.3 (C-2 of Qui), 79.0 (C-3 of Qui), 78.4 (C-3 of Glc'), 78.4 (C-5 of $\left.\mathrm{Glc}^{\prime \prime}\right), 77.8$ (C-2 of Glc), 77.6 (C-3 of Glc"), 77.0 (C-4 of Qui), 76.9 (C-5 of Glc), 76.4 (C-5 of Glc'), 75.5 (C-2 of Glc'), 74.4 (C-2 of Glc'), 74.2 (C-4 of Rha), 72.5 (C-3 of Rha), 72.5 (C-5 of Qui), 72.1 (C-2 of Rha), 71.7 (C-4 of $\left.\mathrm{Glc}^{\prime}\right), 71.2$ (C-4 of Glc'), 70.3 (C-4 of Glc), 70.0 (C-6 of Glc'), 69.4 (C-5 of Rha), 62.5 (C-6 of Glc), 62.4 (C-6 of Glc"), 35.6, 35.4, 34.9, 32.2, 30.5, $30.2,30.0,29.9,29.7,25.9,25.3,25.2,22.9,18.9$ (C-6 of Rha), 18.5 (C-6 of Qui), 14.2 (C-16 of Agl). 
7a: Amorphous powder. Negative-ion FAB-MS m/z: $1049[\mathrm{M}-\mathrm{H}]^{-}, 887$ $[1049-162]^{-}, 741[887-146]^{-}, 725[887-162]^{-}, 579[725-146]^{-}, 417$ $[579-162]^{-}$. HR-negative-ion FAB-MS m/z: 1049.5037 (Calcd for $\mathrm{C}_{46} \mathrm{H}_{81} \mathrm{O}_{26}: 1049.5016$ ). ${ }^{1} \mathrm{H}-\mathrm{NMR}$ spectral data (in pyridine- $\left.d_{5}, 500 \mathrm{MHz}\right) \delta$ : $0.86\left(3 \mathrm{H}, \mathrm{t}, J=7.0 \mathrm{~Hz}, \mathrm{H}_{3}-16\right.$ of $\left.\mathrm{Agl}\right), 1.56\left(3 \mathrm{H}, \mathrm{d}, J=6.5 \mathrm{~Hz}, \mathrm{H}_{3}-6\right.$ of Qui), $1.77\left(3 \mathrm{H}, \mathrm{d}, J=6.5 \mathrm{~Hz}, \mathrm{H}_{3}-6\right.$ of Rha), $2.51\left(2 \mathrm{H}, \mathrm{t}, J=7.0 \mathrm{~Hz}, \mathrm{H}_{2}-2\right.$ of Agl), $3.57(1 \mathrm{H}, \mathrm{dd}, J=9.0,9.0 \mathrm{~Hz}, \mathrm{H}-4$ of Qui), $4.54(1 \mathrm{H}, \mathrm{dd}, J=1.5,11.5 \mathrm{~Hz}, \mathrm{Hb}-$ 6 of $\left.\mathrm{Glc}^{\prime}\right), 4.83(1 \mathrm{H}, \mathrm{dd}, J=3.5,9.5 \mathrm{~Hz}, \mathrm{H}-3$ of Rha $), 4.90(1 \mathrm{H}, \mathrm{d}, J=7.5 \mathrm{~Hz}$, H-1 of Qui), 4.93 (1H, d, $J=7.5 \mathrm{~Hz}, \mathrm{H}-1$ of Glc' $), 5.05(1 \mathrm{H}, \mathrm{m}, \mathrm{H}-5$ of Rha), $5.08(1 \mathrm{H}$, br s, H-2 of Rha), $5.43(1 \mathrm{H}, \mathrm{d}, J=7.5 \mathrm{~Hz}, \mathrm{H}-1$ of Glc'"'), $5.79(1 \mathrm{H}$, d, $J=8.0 \mathrm{~Hz}, \mathrm{H}-1$ of Glc), $6.32\left(1 \mathrm{H}, \mathrm{s}, \mathrm{H}-1\right.$ of Rha) ${ }^{13} \mathrm{C}-\mathrm{NMR}$ (in pyridine$\left.d_{5}, 125 \mathrm{MHz}\right) \delta: 176.1$ (C-1 of Agl), 106.2 (C-1 of Glc'"), 104.6 (C-1 of Glc'), 102.2 (C-1 of Qui), 101.8 (C-1 of Rha), 101.7 (C-1 of Glc), 89.7 (C-3 of Glc), 83.1 (C-3 of Rha), 80.7 (C-11 of Agl), 79.6 (C-2 of Qui), 79.2 (C-3 of Qui), 78.6 (C-3 of Glc' ), 78.6 (C-5 of Glc' $), 78.3$ (C-3 of Glc'"'), 78.1 (C-5 of Glc'"), 77.5 (C-5 of Glc), 77.1 (C-2 of Glc), 77.0 (C-4 of Qui), 76.0 (C-2 of Glc'"'), 74.9 (C-2 of Glc' ), 73.3 (C-4 of Rha), 72.5 (C-5 of Qui), 71.8 (C-4 of Glc'"'), 71.7 (C-2 of Rha), 71.5 (C-4 of Glc'), 70.3 (C-4 of Glc), 69.4 (C-5 of Rha), 63.0 (C-6 of Glc), 62.8 (C-6 of Glc"'), 62.4 (C-6 of Glc'), 35.3, $35.0,34.8,32.3,30.5,30.1,30.0,29.9,29.8,25.7,25.4,25.3,23.0,19.0$ (C6 of Rha), 18.5 (C-6 of Qui), 14.3 (C-16 of Agl).

8a: Amorphous powder. Negative-ion FAB-MS m/z: $1211[\mathrm{M}-\mathrm{H}]^{-}, 1049$ $[1211-162]^{-}, 903[1049-146]^{-}, 887[1049-162]^{-}, 725[887-162]^{-}, 579$ $[725-146]^{-}, 417[579-162]^{-}, 271[417-146]^{-}$. HR-negative-ion FAB-MS $m / z: 1211.5559$ (Calcd for $\mathrm{C}_{52} \mathrm{H}_{91} \mathrm{O}_{31}: 1211.5545$ ). ${ }^{1} \mathrm{H}-\mathrm{NMR}$ spectral data (in pyridine- $\left.d_{5}, 500 \mathrm{MHz}\right) \delta: 0.86\left(3 \mathrm{H}, \mathrm{t}, J=7.5 \mathrm{~Hz}, \mathrm{H}_{3}-16\right.$ of $\left.\mathrm{Agl}\right), 1.55(3 \mathrm{H}, \mathrm{d}$, $J=6.5 \mathrm{~Hz}, \mathrm{H}_{3}-6$ of Qui), $1.75\left(3 \mathrm{H}, \mathrm{d}, J=6.0 \mathrm{~Hz}, \mathrm{H}_{3}-6\right.$ of Rha), $2.50(2 \mathrm{H}, \mathrm{t}$, $J=7.5 \mathrm{~Hz}, \mathrm{H}_{2}-2$ of Agl), $3.56(1 \mathrm{H}, \mathrm{dd}, J=9.0,9.0 \mathrm{~Hz}, \mathrm{H}-4$ of Qui), 3.69 ( $1 \mathrm{H}$, ddd, $J=2.5,5.5,12.0 \mathrm{~Hz}, \mathrm{H}-5$ of Glc $), 3.76(1 \mathrm{H}, \mathrm{dd}, J=9.5,9.5 \mathrm{~Hz}, \mathrm{H}-3$ of Glc), $4.24\left(1 \mathrm{H}, \mathrm{dd}, J=9.5,9.5 \mathrm{~Hz}, \mathrm{H}-4\right.$ of $\left.\mathrm{Glc}^{\prime \prime}\right), 4.42(1 \mathrm{H}, \mathrm{dd}, J=2.0$, $11.5 \mathrm{~Hz}, \mathrm{Ha}-6$ of Glc $\left.{ }^{\prime \prime \prime}\right), 4.75\left(1 \mathrm{H}, \mathrm{d}, J=8.0 \mathrm{~Hz}, \mathrm{H}-1\right.$ of Glc $\left.{ }^{\prime \prime}\right), 4.79(1 \mathrm{H}, \mathrm{d}$, $J=7.5 \mathrm{~Hz}, \mathrm{H}-1$ of Glc' $), 4.81$ ( $1 \mathrm{H}, \mathrm{dd}, J=3.0,9.5 \mathrm{~Hz}, \mathrm{H}-3$ of Rha), $4.88(1 \mathrm{H}$, d, $J=8.0 \mathrm{~Hz}, \mathrm{H}-1$ of Qui), $4.97(1 \mathrm{H}$, brd, $J=11.0 \mathrm{~Hz}, \mathrm{Ha}-6$ of Glc' $), 5.42$ $(1 \mathrm{H}, \mathrm{d}, J=8.0 \mathrm{~Hz}, \mathrm{H}-1$ of Glc'"'), $5.75(1 \mathrm{H}, \mathrm{d}, J=8.0 \mathrm{~Hz}, \mathrm{H}-1$ of Glc $), 6.31$ $\left(1 \mathrm{H}, \mathrm{s}, \mathrm{H}-1\right.$ of Rha). ${ }^{13} \mathrm{C}-\mathrm{NMR}$ (in pyridine- $\left.d_{5}, 125 \mathrm{MHz}\right) \delta: 176.1(\mathrm{C}-1$ of Agl), 106.3 (C-1 of Glc"'), 105.2 (C-1 of Glc'), 104.4 (C-1 of Glc"), 102.3 (C-1 of Qui), 101.9 (C-1 of Rha), 101.5 (C-1 of Glc), 90.9 (C-3 of Glc), 83.2 (C-3 of Rha), 80.8 (C-11 of Agl), 79.5 (C-2 of Qui), 79.2 (C-3 of Qui), 78.5 (C-3 of Glc"'), 78.5 (C-5 of Glc"), 78.3 (C-3 of Glc' $), 78.1$ (C-5 of Glc'"'), 77.9 (C-3 of Glc"), 77.1 (C-4 of Qui), 76.9 (C-2 of Glc), 76.9 (C-5 of Glc), 76.4 (C-5 of Glc'), 76.0 (C-2 of Glc'"), 75.6 (C-2 of Glc"), 74.5 (C-2 of Glc' $), 73.3$ (C-4 of Rha), 72.5 (C-5 of Qui), 71.9 (C-4 of Glc'), 71.9 (C-4 of Glc"'), 71.7 (C-2 of Rha), 71.3 (C-4 of Glc"), 70.4 (C-4 of Glc), 70.1 (C-6 of $\mathrm{Glc}^{\prime}$ ), 69.3 (C-5 of Rha), 62.8 (C-6 of Glc'"'), 62.5 (C-6 of Glc), 62.5 (C-6 of $\left.\mathrm{Glc}^{\prime \prime}\right), 35.3,35.0,34.8,32.3,30.5,30.2,30.0,29.8,29.7,25.7,25.3,25.3$, 23.0, 19.0 (C-6 of Rha), 18.5 (C-6 of Qui), 14.3 (C-16 of Agl).

9a: Amorphous powder. Negative-ion FAB-MS m/z: $1211[\mathrm{M}-\mathrm{H}]^{-}, 1049$
$[1211-162]^{-}, 887[1049-162]^{-}, 741[887-146]^{-}, 725[887-162]^{-}, 579$ $[725-146]^{-}, 417[579-162]^{-}$. HR-negative-ion FAB-MS m/z: 1211.5541 (Calcd for $\mathrm{C}_{52} \mathrm{H}_{91} \mathrm{O}_{31}: 1211.5545$ ). ${ }^{1} \mathrm{H}-\mathrm{NMR}$ spectral data (in pyridine- $d_{5}$, $500 \mathrm{MHz}) \delta: 0.86\left(3 \mathrm{H}, \mathrm{t}, J=7.0 \mathrm{~Hz}, \mathrm{H}_{3}-16\right.$ of $\left.\mathrm{Agl}\right), 1.55(3 \mathrm{H}, \mathrm{d}, J=6.5 \mathrm{~Hz}$, $\mathrm{H}_{3}-6$ of Qui), $1.77\left(3 \mathrm{H}, \mathrm{d}, J=6.0 \mathrm{~Hz}, \mathrm{H}_{3}-6\right.$ of Rha $), 2.50(2 \mathrm{H}, \mathrm{t}, J=7.5 \mathrm{~Hz}$, $\mathrm{H}_{2}-2$ of $\left.\mathrm{Agl}\right), 3.58(1 \mathrm{H}, \mathrm{dd}, J=9.0,9.0 \mathrm{~Hz}, \mathrm{H}-4$ of Qui), $4.80(1 \mathrm{H}, \mathrm{dd}, J=3.0$, $9.5 \mathrm{~Hz}, \mathrm{H}-3$ of Rha), $4.91\left(1 \mathrm{H}, \mathrm{d}, J=7.5 \mathrm{~Hz}, \mathrm{H}-1\right.$ of $\left.\mathrm{Glc}^{\prime}\right), 4.91(1 \mathrm{H}, \mathrm{d}$, $J=7.5 \mathrm{~Hz}, \mathrm{H}-1$ of Qui), $5.02(1 \mathrm{H}, \mathrm{brd}, J=3.0 \mathrm{~Hz}, \mathrm{H}-2$ of Rha), $5.06(1 \mathrm{H}, \mathrm{dq}$ $J=9.5,6.0 \mathrm{~Hz}, \mathrm{H}-5$ of Rha), $5.09\left(1 \mathrm{H}, \mathrm{d}, J=7.5 \mathrm{~Hz}, \mathrm{H}-1\right.$ of Glc $\left.{ }^{\prime \prime \prime \prime}\right), 5.40(1 \mathrm{H}$, $\mathrm{d}, J=8.0 \mathrm{~Hz}, \mathrm{H}-1$ of Glc"'), $5.79(1 \mathrm{H}, \mathrm{d}, J=7.5 \mathrm{~Hz}, \mathrm{H}-1$ of Glc), $6.38(1 \mathrm{H}, \mathrm{d}$, $J=1.0 \mathrm{~Hz}, \mathrm{H}-1$ of Rha). ${ }^{13} \mathrm{C}-\mathrm{NMR}$ (in pyridine- $\left.d_{5}, 125 \mathrm{MHz}\right) \delta: 176.2(\mathrm{C}-1$ of Agl), 106.1 (C-1 of Glc"'), 104.9 (C-1 of Glc"'"'), 104.6 (C-1 of Glc'), 102.2 (C-1 of Qui), 101.8 (C-1 of Rha), 101.7 (C-1 of Glc), 83.6 (C-3 of Rha), 81.6 (C-4 of Glc"'), 80.7 (C-11 of Agl), 79.6 (C-2 of Qui), 79.1 (C-3 of Qui), 78.6 (C-5 of Glc' $)$, 78.6 (C-5 of Glc $\left.{ }^{\prime \prime \prime \prime}\right), 78.4$ (C-3 of Glc' $), 78.3$ (C3 of Glc'"'), 77.4 (C-5 of Glc), 77.1 (C-4 of Qui), 76.4 (C-3 of Glc'"'), 76.3

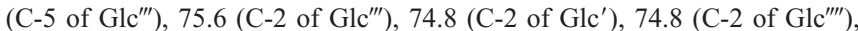
73.2 (C-4 of Rha), 72.5 (C-5 of Qui), 71.7 (C-2 of Rha), 71.5 (C-4 of Glc'), 71.5 (C-4 of Glc'"'), 70.3 (C-4 of Glc), 69.3 (C-5 of Rha), 63.0 (C-6 of Glc), 62.5 (C-6 of Glc'"''), 62.4 (C-6 of Glc'), 62.1 (C-6 of Glc'"'), 35.3, 35.0, 34.8, $32.3,30.5,30.1,30.0,29.8,29.7,25.7,25.3,25.3,23.0,18.9$ (C-6 of Rha), 18.5 (C-6 of Qui), 14.3 (C-16 of Agl)

Acknowledgment We express our appreciation to Mr. H. Harazono of Fukuoka University for his measurement of FAB-MS

\section{References}

1) "Useful Plants of the World," ed. by Hotta M., Ogata K., Nitta A., Hosikawa K., Yanagi M., Yamazaki K., Heibonsha, Tokyo, 1989, p. 197

2) Gaspar E. M., Tetrahedron Lett., 40, 6861-6864 (1999).

3) Gaspar E. M., J. Org. Chem., 2001, 369-373 (2001)

4) Ono M., Takagi-Taki Y., Honda-Yamada F., Noda N., Miyahara K., Chem. Pharm. Bull., 58, 666-672 (2010).

5) Ono M., Honda F., Karahashi A., Kawasaki T., Miyahara K., Chem. Pharm. Bull., 45, 1955-1960 (1997).

6) Ono M., Yamada F., Noda N., Kawasaki T., Miyahara K., Chem. Pharm. Bull., 41, 1023-1026 (1993).

7) Seo S., Tomita Y., Tori K., Yoshimura Y., J. Am. Chem. Soc., 100, $3331-3339$ (1978).

8) Kitagawa I., Nishio T., Kobayashi M., Kyogoku Y., Chem. Pharm. Bull., 29, 1951-1956 (1981).

9) Kasai R., Suzuo M., Asakawa J., Tanaka O., Tetrahedron Lett., 2 , 175-178 (1977).

10) Tori K., Seo S., Yoshimura Y., Arita H., Tomita Y., Tetrahedron Lett., 2, 179-182 (1977). 